\title{
Integrating Local Wisdom Values in Elementary School To Strengthen Students' Caring Character
}

\author{
Amaliyah Ulfah \\ Universitas Ahmad Dahlan \\ Yogyakarta, Indonesia \\ misshomeciul@gmail.com
}

\begin{abstract}
Strengthening students' character is highly relevant to overcome moral crisis in this country. Moral crisis that occurs today is very worrying because it is not only done by adults but also by children. Examples of character aberrations lately are bullying, violence, and sexual harassment among children. Elementary school age is included in the golden period, so this stage becomes the most appropriate momentum to build and strengthen students' character. Caring character can be defined as a sense of interest, affection, and attention to others which will then be embodied in attitudes or behavior in appreciating, receiving, or helping. Effort that can be done to strengthen the children caring character is by integrating the values of local wisdom in learning. One example of integrated local wisdom in thematic lesson 1 of "My Interest" with the subtheme Singing and Dancing is a song entitled "Dhondong Apa Salak". The message conveyed in this song is that as humans we should not judge a person by appearance. Every person is also created differently like sweet salak fruit and sour kedondong. Therefore, people must respect each other.
\end{abstract}

Keywords - character, caring, elementary school, school

\section{INTRODUCTION}

It must be admitted that Indonesia is experiencing a very apprehensive crisis that is the increasing of intolerance. This can lead to divisions for the nation of Indonesia because it is a diverse country consisting of various tribes, religions, and cultures. Intolerance attitudes are also increasingly diverse in forms. This intolerant actions are also committed by school students.

Based on a survey conducted by the Ministry of Social, $84 \%$ of children aged $12-17$ years had been the victim of bullying. In addition, based on the information from Telepon Sahabat Anak (Tespa), there have been 976 complaints about bullying among children since January - July 2017. Meanwhile, psychologist Muhammad Iqbal mentioned that cases of violence against children in 2014 were considerably high. Although in 2015 and 2016 the number decreased, but in 2017 similar cases reappeared. A recent mistreatment case in August 2017, a second grade elementary student in Sukabumi district, West Java died after being beaten by his classmates (source: www.tribun.com). Another similar case example happened to the fourth grade elementary school students in Kudus, Central Java. A female student was beaten, and her hair was shaved by her nine classmates because she did not want to fulfill the gang leader's wish (source: www.kompas.com).

The number of irregularities cases among children is very tragic. Low law enforcement in our country and the ineffectiveness of education outcomes have been considered the factors influencing the increase of students' misbehaviors. Many theories and research results indicate that one of the causes of values and morality decline is because the education system in Indonesia emphasizes too much on cognitive aspects. Lessons learned tend to focus on memorization so that students are not well motivated. Ref [1] also argues that current education focuses too much on knowledge aspect, and is less able to develop values, attitudes, and character.

Tolerant character should be taught as early as possible in both family and school environment. The instilling of characters in family is very important because the family is the first place where children socialize. Furthermore, character education needs to be emphasized in elementary to secondary schools. Ref [2] describes three designs of character education in a school, namely a) integrated in the curriculum, b) through extracurricular activities, and c) through self-development activities.

Therefore, one of the steps to strengthen children character is by integrating local wisdom in learning or curriculum. Indonesia is known as a country which is rich in culture and values among society. The living values used as a reference in character education is the value that comes from local society. It is essential that learning materials in elementary school are also derived from local wisdom values in the area. By integrating the values, students are expected to have a strong personality and are always ready towards real life situations.

\section{METHOD}

\section{A. Importance of Building Elementary Students' Caring Character}

Children's character needs to be established and should be educated as early as possible. According to Freud [1], children 
who fail to grow with good personality at an early age tend to be troublesome in adult life. Many experts also say early childhood included in the golden age is a critical period for the shaping one's character. Therefore, this stage is the best momentum for children's physical and brain development.

The word character is derived from Latin root, which means "carved" (Rutland in [3]). If illustrated to a granite stone, it is carefully carved in the end and it will produce a remarkable masterpiece, whereas if beaten improperly, it will become broken. Therefore, character is a compound of virtues and values carved in stone and will declare its true values.

Caring according to [4] is defined as "feeling, interest, or affection for someone or something". Thus, caring is an attraction or affection to someone or something else. Ref [5] explains caring as an act of being concerned about or interested in another person or situation. It is feeling or acting with compassion, concern, or empathy. Caring is an act that shows interest in others or is concerned with the surroundings. It is a feeling or acting with affection, attention, or empathy. Moreover, [6] describes the act of caring as follows.

I reach out to help people who are in painful situation.

I am kind to family members.

I am kind to stranger.

I can work to resolve a conflict peacefully; and forgive others.

I offer to help others without being asked to do so. I express thank to other and can show my gratitude in a variety of ways.

Caring character can be interpreted as interest, affection, attention to others or to something else and then is manifested in attitudes of respect, acceptance, or help. Caring does not come for granted, but it needs to be known, understood, realized, and manifested in everyday life. The duty of teachers in the school is to cultivate learners' awareness to other students, teachers, or environment.

Children's interest and caring toward values continue to develop up to adulthood phase, Table 1 presents children developmental phase of interest and caring towards values adapted from K Egan in Values and Ethics and the Science and Technology Curriculum [7].

TABLE 1. STAGES OF CHILDREN'S INTEREST AND CARING TOWARDS VALUES

\begin{tabular}{|c|l|}
\hline Stage type (age) & \multicolumn{1}{|c|}{ Characteristic of Children's Development } \\
\hline $\begin{array}{c}\text { Myth Stage } \\
\text { age 5-10) }\end{array}$ & $\begin{array}{l}\text { Children learn through playing and telling stories. They } \\
\text { are happy to play with a toy that involves their feelings. } \\
\text { At this stage, moral value becomes the main concern } \\
\text { distinguished in black and white such as good and ugly, } \\
\text { love and hate, like and dislike. }\end{array}$ \\
\hline $\begin{array}{c}\text { Romantics } \\
\text { Stage }\end{array}$ & $\begin{array}{l}\text { In this stage, children expect a lot of information that can } \\
\text { provide a description of humans, spirits, adventures, } \\
\text { technological developments, sports, up to the problems } \\
\text { which are unfamiliar to them. }\end{array}$ \\
\hline $\begin{array}{c}\text { Philosophy } \\
\text { Stage }\end{array}$ & $\begin{array}{l}\text { This stage is mainly dominated by the desire of } \\
\text { adolescents to simplify the sequence of experience } \\
\text { through self-made conclusions or through standard legal } \\
\text { and regulatory arrangements. At this stage, children are } \\
\text { usually frustrated when they get special treatments or } \\
\text { there is opposition in terms of law enforcement. }\end{array}$ \\
\hline
\end{tabular}

\begin{tabular}{|c|l|}
\hline $\begin{array}{c}\text { Ironic Stage } \\
\text { (age 20 above) }\end{array}$ & $\begin{array}{l}\text { At this stage, the teenagers or adults try to seek clearer } \\
\text { conclusions based on their knowledge and experience. At } \\
\text { this stage, late adolescents no longer feel frustrated by } \\
\text { the presence of conflict and contradiction. }\end{array}$ \\
\hline
\end{tabular}

Based on Table 1, elementary schools are considered mostly at the stage of myth. At this age, moral values of goodbad, good-bad, love-hate, like and dislike become the main focus of their attention. Therefore, if the concept of rightwrong, good-bad, good-bad is delivered to the child from the beginning, it can be fatal. Introduction of this concept to elementary school students can be conveyed by involving their feelings through telling stories, role playing, singing, and exploring moral experiences.

\section{B. Values in Local Wisdom}

According to [8], local wisdom is a heritage of ancestors related to the values of life". Values of life can be the form of a value or norm, religions, law, ethics, and all of which are inherited from the ancestors. Geertz [9] defines local wisdom as a part of culture. Local wisdom is traditional culture element that is deeply rooted in human life and community related with human resources, source of culture, economic, security and laws. Local wisdom can be viewed as a tradition related with farming activities, livestock, building house, and so on.

According to [10] local wisdom includes: (a) thoughts, attitudes, and actions of language, arts such as literary and philosophical works, (b) attitudes and actions in various cultural artifacts, such as keris (traditional weapon), temple, decoration, painting, etc., (c) social thoughts and attitudes, such as manners and politeness. Cultural dimensions include: (1) traditional ceremonies, (2) cultural preservation, (3) natural tourism, (4) traditional transportation, (5) traditional games, (6) cultural infrastructure, (9) museums, (10) cultural institutions, (11) arts, (12) cultural villages, (13) arts and crafts, (14) folklore, (15) children's games (dolanan), and (16) puppets.

Local wisdom will be eternal if it is implemented in everyday life to respond and respond changes [11]. According to [9], culture cultivated from local wisdom is not a barrier to advancement of global era. Instead, it can be a tremendous cultural filter and transformational power in the glory of the nation.

Variety of local wisdom is a potential for students' character building and current education system should immediately design and integrate the values in learning.

\section{Strengthening Elementary School Students Character through the Values of Local Wisdom}

The noble values sourced from local wisdom of every region are relevant to be implemented in school to strengthen students' character, especially elementary students who are still in the crucial stage of moral development. The forms of local wisdom that can be integrated in thematic learning in elementary schools are folklore, regional songs, proverbs, and games. 
One example of local wisdom that can be integrated in elementary school is the dolanan song entitled "Dhondong Apa Salak". This song originates from Central Java and can be integrated in thematic lesson 1 of My Interest, with the subtheme of Singing and Dancing. In addition to singing, children are also taught to understand the messages of the song.

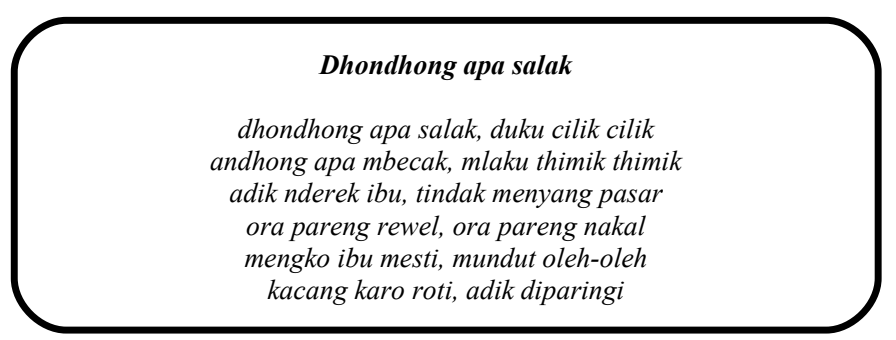

\section{Philosophical Meanings of Dondong Apa Salak}

a. Dhondong or kedondong is a fruit that looks smooth outside, but it has rough and sour meat inside. In life, it can be illustrated as one who is well dressed but is bad in attitude.

b. Salak fruit is the fruit which has opposite in form from dondong, It has rough and sharp peels, but it has sweet and delicious meat.

c. It is in contrast to duku fruit. Duku is a fruit that both looks smooth from the outside and has smooth and sweet meat inside.

d. Andhong or pedicab is a vehicle that requires human or horse power.

e. Mlaku thimik thimik means slow but safe.

The character values of the song are as follows:

- As human beings we should not judge a person by their appearance (we should not do prejudgment to anyone).

- Every person is also created differently like salak which tastes sweet, and kedondong which tastes sour. Therefore, we must respect each other.

If we have big dreams, it cannot be accomplished instantly. Instead, it needs long a process which require us to be more careful and patient.

\section{CONCLUSION}

Elementary school age is included in the golden period, so this stage becomes the most appropriate momentum to build and strengthen one's character. Caring character means of interest, affection, attention to somebody or to something else and then is manifested in attitudes of respect, acceptance, or help. The effort that can be done to strengthen the children's caring character is by integrating the values of local wisdom in elementary school learning. Values in local wisdom can be powerful filters if they are integrated in elementary school learning.

\section{REFERENCES}

[1] M. Muslich, Pendidikan karakter menjawab tantangan krisis multidimensional, Jakarta: Bumi Aksara, 2011
[2] D. Kesuma, C. Triatna, dan J. Permana, Pendidikan karakter kajian teori dan praktik di sekolah, Bandung: Rosda, 2011.

[3] F. Hidayatullah, Peningkatan kualitas pendidik dalam membangun karakter peserta didik, Disampaikan dalam Seminar Nasional Ikatan Alumni UNY, 2011.

[4] N. Stevenson, Young person's character education handbook, United States of America: JIST Publishing, 2006.

[5] S. L. McElmeel, Character education (a book guide for teachers, librarians, and parents), United States of America: Teacher Ideas Press, 2002.

[6] J. Freed, Character Empowering With Emotional Intelligence, Santa Barbara: In Depth Press, 2006

[7] UNESCO, Values and Ethics and The Science and Tecnology Curriculum, Bangkok: Principal Regional Office for Asia and The Pacific, 1991

[8] Suhartini, "Kajian Kearifan Lokal Masyarakat dalam Pengelolaan Sumberdaya Alam dan Lingkungan," Prosiding Seminar Nasional Penelitian, Pendidikan dan Penerapan MIPA (Yogyakarta: Fakultas MIPA, Universitas Negeri Yogyakarta), 2009, pp 206-208.

[9] Wagiran, "Pengembangan Karakter Berbasis Kearifan Lokal Hamemayu Hayuning Bawana”, Jurnal Pendidikan Karakter, tahun II, No.3, 2012

[10] Wagiran, Pengembangan Model Pendidikan Kearifan Lokal di Wilayah Provinsi DIY dalam Mendukung Perwujudan Visi Pembangunan DIY Menuju Tahun 2025 (Tahun Kedua), Penelitian, Yogyakarta: Biro Administrasi Pembangunan, 2010

[11] U. Fajarini,"Peranan Kearifan Lokal Dalam Pendidikan Karakter”, Jurnal Sosio Didaktika; Vol.1, No.2, 2014 